\title{
MOLECULAR GENETICS AND SSR MARKERS AS A NEW PRACTICE IN FARM ANIMAL GENOMIC ANALYSIS FOR BREEDING AND CONTROL OF DISEASE DISORDERS
}

\author{
A.Teneva $^{1}$, K. Dimitrov ${ }^{2}$,V. Caro Petrović ${ }^{3}$, M.P.Petrović ${ }^{3}$, I. Dimitrova ${ }^{1}$, \\ N.Tyufekchiev ${ }^{4}$, N.Petrov ${ }^{5}$ \\ ${ }^{1}$ University of Forestry, 1756 Sofia, Bulgaria \\ ${ }^{2}$ National Diagnostic and Research Veterinary Medicine Institute, 1606 Sofia, Bulgaria \\ ${ }^{3}$ Institute of Animal Husbandry, 11081 Belgrade-Zemun, Serbia \\ ${ }^{4}$ Progene Ltd., 1000 Sofia, Bulgaria \\ ${ }^{5}$ Institute of Soil Science, Agrotechnologies and Plant Protection"Poushkarov", 1080 Sofia, Bulgaria \\ Corresponding author: nas15@abv.bg \\ Review paper
}

\begin{abstract}
Molecular genetics investigates the genetic makeup of individuals at the DNA level. That includes the identification and mapping of molecular genetic markers and genetic polymorphisms. Molecular genetic markers (DNA markers) are one of the most powerful means for the genomic analysis and allow the connection of hereditary traits with genomic variation. Molecular marker technology has developed rapidly over the last decade and two shapes of specific DNA based marker, Simple Sequence Repeats (SSRs), also known as microsatellites, and Single Nucleotide Polymorphisms (SNPs) prevail applications in modern genetic analysis.Genomic simple sequence repeats (SSRs, microsatellites) have been used for a variety of purposes, including gene tagging, physical mapping, genome mapping, estimation of genetic diversity, phylogenetic and conservation genetic purposes in farm animal breeding. SSR analyses are applied successfully in parentage verification and pedigree analysis, as disease markers and to locate the mutation in genetic disorders in livestock animals. The ultimate use of SSRs markers is for mapping quantitative trait loci (QTL), marker assisted selection (MAS) in order to practice genomic selection and improve the farm animal health. Developments in 'omics' technologies, such as genomic selection, may help overcome several of the limitations of traditional breeding programmes and will be especially beneficial in breeding for lowly heritable disease traits that only manifest themselves following exposure to pathogens or environmental stressors in adulthood. The current paper provides a brief overview of the present - day application of microsatellites markers in animal breeding and make significant contribution to the overall farm animal health and resistance to disease.
\end{abstract}


Key words: molecular markers, microsatellites, QTL, MAS, animal health

\section{Introduction}

Molecular Genetics deals with the genomic makeup of individuals at the DNA level. It is the identification and mapping of genes, DNA markers and genetic polymorphisms ( Teneva et al.,2005,2007,2009;Teneva, 2009). This enables us to use molecular genetics to identify the genes and other molecular markers that are involved in variety of productive traits. On the base of the information of genomic makeup it would be possible to select improved livestock. In case it is carefully applied, the use of molecular information in selection programmes has the power to increase productivity of farm animals, as well as to enhance environmental adaptation and maintain genetic diversity.

Conventional animal's breeding programmes depend on selection programmes based on phenotypic selection ( Walsh, 2000, Teneva and Petrovic, 2010). This resulted in the selection of a number of economically important genetic traits in cattle, sheep, pigs and poultry. In phenotypic selection traits are measured directly and animals with superior performance are used as breeding stock where the trait is limited, such as production, progeny test schemes have allowed the genetic merit of the sex not displaying the trait to be estimated (Dekkers, 2004; Naqvi, 2007). There are sundry stumpers related to the phenotypic selection:

restriction of the genetic base of a population

- it could be carried out to traits that are facilely evaluated

- requiring high costs

- the difficulties in improving disease resistance in farm animals by traditional phenotype selection.

For the traits that are displayed only in adults, which include most of the production traits, it is necessary to raise a large number of individuals for which the trait is recorded, so that a few can be chosen for breeding. In the case of progeny testing for milk production, the costs are very high, as the test sires have to be raised and then the daughters themselves raised and bred before the trait can be measured and the elite sires selected (Naqvi, 2007).

Improved animal health is a major objective in current animal breeding strategies, but is difficult to achieve by traditional breeding methods. Thus, selection for genetic disease resistance provides a potential avenue for improving the health status of farm animals, increasing productivity and reducing the need for pharmaceutical intervention, in this way reducing costs and delaying the appearance of resistant pathogens. The achievement of such improvement is one of the most important applications of molecular genome research. 
In 1940`s Irwin and co-workers used blood group antigens for parentage verifications in the Holstein Friesian cattles (Hines, 1999). Later, in the 1950's Stormont (Hines, 1999) studied the blood groups in cattle and their applications in the detection of incorrect parentage. Landsteiner in the early 1900's on human blood group variability and Erlich and Morgenroth and Todd and White on blood groups in farm animals researched into immuno-genetics and genetic variability among animals (Hines, 1999; Marle-Köster and Nel, 2003).

It is, however the development of molecular biology and especiallay DNA based markers during the past three decades that created exciting new means for studying livestock genetics and animal breeding. Selection according to genotype has become an important tool in the breeding of farm animals. In very recent years the molecular biological approach has also been revolutionized by the application of new technologies (Hayes et al., 2009).

\section{Molecular Marker Technologies}

In this regard the use of molecular genetic technologies potentially offer a way to select breeding animal at an early age and to select for a broad range of traits as well as to enhance reliability in predicting the mature phenotype of the individual (Weir et al., 2006; Naqvi, 2007; Toro at al., 2009; Hayes et al., 2009). The several categories of potential gene - based implementations are in:

- Animal identification and traceability

- Molecular-genetic analysis of genetic diversity

- Reproductive improvement

- Transgenic livestock

- Gene based trait selection

- Animal health: diagnosis, protection and treatment

- Nutrition and metabolism

Molecular genetics allows to study the genetic make-up of individuals at the DNA level. The use of molecular genetics in selection programmes is based on the ability to determine the genotype of individuals for mutations or indirect markers using DNA analysis. This information is then used to assess the genetic value of the individual,which can be captured in a molecular score that can be used for selection (Dekkers and Hospital, 2002).

After a lot of authors (Dekkers and Hospital, 2002; Womack, 2005; Naqvi, 2007) the main reasons why molecular genetic information can result in greater genetic gain than phenotypic information are:

$>$ Assuming no genotyping errors, molecular genetic information is not affected by environmental effects and, therefore, has heritability 
> Molecular genetic information can be available at an early age, even at the embryo stage, thereby allowing early selection and reduction of generation intervals

$>$ Molecular genetic information can be obtained on all selection candidates, which is especially beneficial for sex-limited traits, traits that are expensive or difficult to record, or carcass traits (traits that require slaughter)

Molecular genetic markers represent one of the most powerful tools for the analysis of genomes and enable the association of heritable traits with underlying genomic variation. Molecular marker technology has developed rapidly over the last decade and two forms of sequence based marker, Simple Sequence Repeats (SSRs), also known as microsatellites, and Single Nucleotide Polymorphisms (SNPs) now predominate applications in modern genetic analysis.

\section{Simple Sequence Repeats (SSRs) markers}

SSRs also known as microsatellites are short sequence elements that are arranged in a simple internal repeat structure (Awadalla and Ritland, 1997; Moxon and Wills, 1999; Duran et al., 2009). These are very powerful genetic markers, due to their genetic codominance, abundance, dispersal throughout the genome, multiallelic variation, high reproducibility and high level of polymorphism, could characterize and discriminate all genotypes (Tautz, 1989; Schlotterer and Tautz, 1992; Li et al., 2002).

SSRs provide a number of advantages over other molecular markers, namely that multiple SSR alleles may be detected at a single locus using a simple PCR based screen, very small quantities of DNA are required for screening, and analysis is amenable to automated allele detection and sizing (Schlotterer, 2000)

Studies of the potential biological function and evolutionary relevance of SSRs is leading to a greater understanding of genomes and genomics (Subramanian et al., 2003). SSRs were primarilly considered to be evolutionally neutral (Awadalla and Ritland, 1997). More recent data suggests that they probably play an important role in genome evolution (Moxon and Wills, 1999) and provide points of recombination.

They are assumed to be involved in gene expression, regulation and function (Gupta et al., 1994; Kashi et al.,1997) and have been found to bind nuclear proteins and function as transcriptional activating elements ( $\mathrm{Li}$ et al., 2002), scilicet they suggested to have a significant functional role.

SSR analyses are applied successfully in parentage verification and pedigree analysis, as disease markers and to locate the mutation in genetic disorders in livestock animals. The ultimate use of SSRs markers is for mapping 
quantitative trait loci (QTL) and in marker assisted selection (MAS) in order to practice genomic selection.

\section{Ssr Marker Applications In Animal Genetics And Breeding}

The main properties of the SSRs markers - abundance, hypervariability and Mendelian inheritance make them very informative markers in the genome analysis and are used for various applications in many livestock species (Tautz, and Renz, 1984; Tóth et al., 2000; Beuzen et al., 2000; Binadel et al., 2001; Katti et al..2001; Adamov et al., 2011) in individual identification, parentage and pedigree analysis, genome mapping, population genetics, conservation and management of biological resources.

\section{Individual identification, parentage and pedigree analysis}

Allozymes are not the best markers for estimation of hereditary relationship because of their restricted ability for sampling the genome as a whole. The most effective marker for this type of evaluation are microsatellites as they are codominant and hypervariable (thus able to distinguish between closely related individuals) (Chakraborty et al.,1988). In general, only 30-40 microsatellite loci are needed to provide a satisfactory estimation of relationship (Blouin, 2003).

The PCR based microsatellite typing provide the powerful tool for the identity and the paternity testing. Selected panel of microsatellite loci and the multiplex PCR system form a highly discriminating powerful tool for parentage testing (Peelman et al., 1998; Luikart et al., 1999).

The microsatellites have been successfully and extensively employed for the parentage testing and individual identification for the breed allocation etc., in various domestic animals - cattle, dogs, horses (Fredholm and Wintero, 1996; Bowling et al., 1997; Guerand et al., 1997; Peelman et al., 1998; Alter et al., 2001; Bjornstad and Roed, 2001; Adamov et al., 2011). Coppieters et al. (1993), based on the observed allele frequencies in the studied pig populations, estimated the exclusion probability for the quadruplex microsatellites to be 0.96 . Kaul et al. (2000) estimated the probability of identity of two random individuals from the two different native Indian pig populations, based on 13 microsatellites, to be $3.51 \times 10$ 19.

In 2004 Gentilini and coworkers used a DNA fingerprint technique based on microsatellites to solve a parentage testing in Boxer breed.

The concept of genetic relatedness and parentage is central to many aspects. In agriculture, measurements made on related individuals can be used to estimate the additive and dominance components of variance, which in turn are 
needed to predict the gain from breeding programmes for domesticated animal species (Weir et al., 2006; Selkoe and Toonen, 2006).

The multiallele microsatellites are currently using as modern genetic markers to assess the degree of relatedness between individuals or to address suggested degrees of relatedness (Weir et al., 2006).

\section{Population analyses/estimation of genetic diversity}

The high degree of the polymorphism of SSR markers makes them the markers of choice for such studies over the conventional markers like the restriction fragment length polymorphism (RFLP), which generally have only two alleles, and has a maximum theoretical heterozygosity of 50\% (Botstein et al., 1980, Teneva et al., 2005). The microsatellites give discriminating and significantly concordant results as compared to RAPD (Zhanjiang, 2007).

Since the beginning of the $1990 \mathrm{~s}$, microsatellite molecular data have become more suitable for the characterization of genetic diversity (Bowcock et al., 1994; Laval et al., 2000; Groeneveld et al., 2010). Fredholm et al. (1993) characterized 24 porcine $(\mathrm{dA}-\mathrm{dC}) \mathrm{n}-(\mathrm{dT}-\mathrm{dG}) \mathrm{n}$ microsatellites for genotyping of the four European pig breeds. The variation between the Chinese indigenous Meishan and the Western breeds was also studied using the microsatellite markers (Paszek et al., 1998b). Li et al. (2000b) reported variation among the seven local pig breeds of China using the six microsatellite loci. Niu et al. (2001) analysed the 5 lines of pig inbred lines with the 35 microsatellite loci. In order to clarify the genetic relationships among the major pig breeds is necessary to use the common set of the microsatellites for analysis of the genetic diversity.

To maintain the concordance of the results so that the data can be compared at the international level, the Food and Agricultural Organisation (FAO) has recommended the use of a species specific set of microsatellite markers for molecular characterization in following farm animals - cattle, buffalo, sheep, goat, horse, donkey, pig and chicken $(F A O, 2011)$. These guidelines revise and build upon the Secondary guidelines: measurement of domestic animal diversity (MoDAD) published by FAO in 1993.

Genetic population studies using the microsatellites help in rating the genetic variation within and between the breeds and to define a diversity measure which will permit the ranking of the breeds for conservation purpose thus providing the useful information concerning the relative contribution to the genetic diversity (Laval et al., 2000, Martinez et al., 2000; Behl et al., 2002). This will allow for the future management of the breeds to be based on the greater knowledge of their genetic structure and the relationships between breeds for conservation breeding purposes (Takezaki and Nei, 1996; Caballero and Toro, 
2002; Aberle and Distl, 2004; Kim et al., 2004; Taberlet, et al., 2008; Toro et al., 2009).

Commonly, neutral molecular markers have some clear advantages when used to estimate the genetic diversity of populations: they are relatively easy to characterize, and they can provide unbiased estimates of random processes such as genetic drift (Luikart et al,. 2003). Microsatellites are currently the most widely used markers for inferring genetic diversity. One of the purposes of genetic diversity studies is to manage, preserve and disseminate these to breeding organizations and relevant government agencies (FAO, 2011). Many studies refer microsatellites exploitation for genetic diversity evaluation and relationships among cattle populations (MacHugh et al., 1997; Canon et al., 2001; Kim et al., 2002; Maudet et al., 2002; Dorji et al., 2003; Jordana et al., 2003; Metta et al., 2004; Mukesh et al., 2004; Pandey et al., 2006).

The genetic diversity of eleven pig breeds from six European countries along with a small sample of wild pigs was evaluated by Laval et al. (2000) using 18 microsatellite markers. Significant breed differentiation $(F S T=0.27)$ and moderate diversity $(\mathrm{He}=0.35$ to 0.60$)$ was observed amongst the eleven breeds with the French Basque found to be the most genetically distinct. During the PigBioDiv I project (Ollivier et al., 2005; Ollivier, 2009), 58 European populations including 29 local breeds, 18 national varieties of international breeds, 21 commercial lines and the Chinese Meishan breed, used as an out-group were genotyped for 50 microsatellite markers. Data from 11 breeds generated during the PiGMap project (Laval et al., 2000) were also included in the analysis. These data showed that the individual breed contributions to between breed diversity ranged from $0.04 \%$ to $3.94 \%$ of the total European between breed-diversity, and that local breeds accounted for $56 \%$ of the total, followed by commercial lines and international breeds.

Kim and Choi (2002) used six microsatellite loci on 67 individuals to characterize genetic variability and structure of Korean native black pigs. Thuy et al. (2006) analysed five Vietnamese indigenous breeds and showed a higher degree of polymorphism, allelic diversity, and heterozygosity than in the commercial pigs of European origin.

The preliminary findings from the microsatellite data of the indigenous pigs from Bhutan, Nepal, Sri Lanka, and Papua New Guinea, which have been recently reported (Nidup et al.,2010a; Nidup et al., 2010b) suggest rich biodiversity of indigenous pigs resource in South Asia and Papua New Guinea. All these microsatellite studies indicate the existence of biodiversity, potential conservation, and sustainable utilization of swine genetic resources, particularly the indigenous breeds, in European and Asian countries.

\section{Microsatellite markers for the gene mapping/ linkage analyses}


The excellent properties of the microsatellites makes them an effective tool for linkage studies and gene mapping. There are several advantages in using of microsatellites for the genome wide linkage search (Peelman et al., 1998, Teneva, 2009): their ubiquity in the genome, a small number of the families will be sufficient to prove or disprove the linkage because of the highly polymorphism, multiple microsatellites can be analysed simultaneously since several loci can be amplified in the single PCR.

The genetic linkage analysis is based on the principle that if two genes on the DNA segment are located close to each other on the same chromosome, they are likely to be inherited together. The linkage between the two genetic loci is established when they show significant co-segregation in the offspring (Duran et al., 2009). The microsatellite markers scattered throughout the mammalian genome, are probably best markers available for linkage studies. Linkage maps solely or mostly built up by microsatellite markers have been reported for various species of farm animals (Barendse et al., 1994; Ellegren et al., 1994; Archibald et al., 1995; Kappes et al., 1997; Binadel et al., 2001; Ellegren, 2004; Takahashi et al., 2005).

The linkage maps for the genomes of the pig and other domestic animals are important as these genetic maps have made it possible to map the disease genes and their potential ability to genetically dissect the phenotypic traits of the agricultural or biological significance. Marklund et al. (1999) identified a linkage group of three microsatellite loci, blood groups L, GBA and ATP1B1 on the pig chromosome. Hasan and coworkers (1999) employed the 14 microsatellites to map the $\mathrm{L}$ oxidase gene, which is a candidate for the vitamin $\mathrm{C}$ deficiency in to the chromosome 14. A whole genome scan was conducted using 132 microsatellite markers to identify the chromosomal regions that have an effect on the teat number in the Chinese Meishan pigs and the five commercial Dutch pig lines (Hirooka et al., 2001).

The microsatellite loci have been also used for detection and localisation of the quantitative trait loci for the growth and fatness in the pigs (Marklund et al., 1999; Binadel et al.,2001). The molecular genome scan analysis to identify the chromosomal regions influencing the economic traits in the pigs using the microsatellites have been reported for the teat number by Malek et al. $(2001 a, b)$. The information may subsequently utilized for the breeding programmes in domestic animals through marker assisted selection (MAS).

\section{QTL mapping by the use of microsatellite markers}

Over the last decade considerable effort has been put into the construction of genetic and physical maps of the genomes of livestock species (Dekkers, 2004; Willijams, 2005; Erhardt and Weimann, 2007, Teneva et al., 2007). In the first 
instance these maps were composed predominantly of anonymous, microsatellite markers. The bovine genetic map now contains over 3,800 markers (Ihara et al., 2004). These genetic maps have been used to select markers that are distributed across whole genome. These markers are then used in QTL mapping studies to track the inheritance of specific regions of chromosomes through generations of families. Microsatellite markers are commonly used in these studies because they usually have several alleles and hence the parental origin of a particular marker can usually be determined to track the inheritance of specific regions of chromosomes through generations of families (Dekkers, 2004; Duran et al., 2009).

Until recently, microsatellites were the markers used for mapping quantitative trait loci for production and functional traits in farm animals (Hiendleder et al., 2003; Kühn et al., 2003) and tightly linked markers are used for marker assisted selection in practice. They are also the prerequisite for the identification of positional and functional candidate genes responsible for quantitative traits.

Genome scans for QTL are completed for all major livestock species ( http://www.animalgemome.org/QTLdb/; http://bovineqtl.tamu. edu/index.html). When marker-QTL associations are identified, MAS can be applied in breeding programmes with the aim of improving selection response (Meuwissen and Goddard, 1996). In German Holstein cattle a whole genome scan was performed and QTLs for functional traits (Kühn et al., 2003), body conformation and behaviour were identified (Hiendleder et al., 2003).

Using an identical design Harder et al. (2006) detected QTL for lactation persistency traits in cattle. On the basis of a QTL identified on BTA 18, it could be shown using comparative mapping strategies, that it is possible to identify a candidate gene. DGAT1, the gene encoding diacylglycerol O-acyltransferase, was identified a candidate gene for milk production traits by Grisart et al. (2002) and Winter et al. (2002). Since DGAT1 has main effects on the fat content of milk, the analyses of promoter variants of the bovine aS1-casein (CSN1S1) gene lead to a significant effect on the protein percentage in dairy cattle (Prinzenberg et al., 2003). The effect of DGAT could be further differentiated by including CYP11B1 variants (Kaupe et al., 2007).

\section{Marker assisted selection (MAS)}

A major objective of quantitative trait loci (QTL) studies is to find genes/markers that can be implemented in breeding programs via marker assisted selection (MAS). There is a general agreement from theoretical and simulation studies that application of MAS has the potential to increase the rate of genetic gain especially if traditional selection is less effective (Khatkar et al., 2004) 
Since the 1970s, the discovery of technology that enables identification and genotyping of large numbers of genetic markers, and research that demonstrated how this technology could be used to identify genomic regions that control variation in quantitative traits and how the resulting QTL could be used to enhance selection, have raised high expectations for the application of gene- (GAS) or marker-assisted selection (MAS) in livestock. Yet, to date, the application of GAS or MAS in livestock has been limited (Dekkers, 2004).

After Dekkers( 2004) the successful application of MAS in breeding programmes requires advances in the following five areas:

- Gene mapping: identification and mapping of genes and genetic polymorphisms.

- Marker genotyping: genotyping of large numbers of individuals for large numbers of markers at a reasonable cost for both QTL detection and routine application for MAS.

- QTL detection: detection and estimation of associations of identified genes and genetic markers with economic traits.

- Genetic evaluation: integration of phenotypic and genotypic data in statistical methods to estimate breeding values of individuals in a breeding population.

- MAS: development of breeding strategies and programmes for the use of molecular genetic information in selection and mating programmes.

Advances in MAS have been made in all farm animal species principally on the base of microsatellite being the marker of choice for QTL searching and gene mapping.

In dairy cattle, after the first work of Georges et al. (1995), many large scale QTL detection experiments were designed to exploit the population structure and the recording systems existing in large dairy breeds. Most of them used the socalled granddaughter design. A recent review (Khatkar et al, 2004) summarized the results of more than 50 experiments and presented a meta-analysis.

To date, only few QTL have been fully characterized with a strong putative or well-confirmed causal mutation: DGAT1 on chromosome 14, GHR on chromosome 20, or SPP1 on chromosome 6 (Boichard et al., 2006) They all affect milk production traits, whereas no QTL affecting functional traits such as fertility or mastitis resistance has been characterized so far.

To the authors' knowledge, MAS development still remains limited due to some limiting factors including biological factors (reproductive capacity) and many theoretical considerations related to the effectiveness of MAS (e.g. diverting selection pressure from polygenes to a single marked gene), which are generally applicable to MAS in livestock, its cost, its high organisational demand, to the limited number of genes of importance fully characterised, and also to some lack of confidence of users (Muir, 2003; Dekkers, 2004; Boichard et al., 2006). 


\section{Microsatellites for identification and control of disease disorders in livestock}

In molecular genetics, there have been considerable advances in animal breeding and genetics, relevant to animal disease control. These advances are of considerable veterinary interest, showing that observed animal performance is the outcome of the interaction between the animal's genetic makeup and the specific environment it was exposed to. Thus improved genetics has the potential to complement current approaches to animal disease control. Improvement in animal health through genetic selection is advantageous, because genetic gain is cumulative and permanent, as the genes introduced into a population can persist for many generations (Berry et al., 2011).

Microsatellite sequences are most commonly employed in determining progress in identification and control of livestock disease disorders (Berry et al., 2011).

Kriegesmann et al. (1997) mapped genes for genetic diseases such as BLAD in cattle and developed a DNA test to identify the unfavourable allele. Fujii et al. (1991) studied the gene variant in pigs responsible for the maligne hyperthermia syndrome (MHS), which is closely related to meat quality. Both tests are successfully implemented within breeding programmes in the breeds affected and have reduced the frequency of the unfavorable allele.

Of great interest are the markers that are linked to disease resistance QTL, like E.coliresistance in pigs (Meijerink et al., 2000), nematode resistance in sheep (Coltman et al., 2001), trypanotolerance in cattle (Hanotte et al.,2003). Peelman (1999) identified four microsatellites as the preliminary diagnostic tool to type pigs for the K88 E. coli neonatal diarrhea resistance or sensitivity.

A lot of candidate microsatellite loci were selected as markers associated with different livestock diseases: markers located in the ovine MHC (Crawford et al., 1995), INRA111 and INRA131 for bovine mastitis (Schulman et al., 2004), CP26 for tuberculosis (Acevedo-Whitehouse et al., 2005).

The presence and frequence of microsatellites instability (MSI) could be used for detecting diseases or tumors (McNiel et al., 2007; Sotirakopoulos et al., 2010; Zhou et al., 2012). Microsatellite mutations or microsatellite instability (MSI) leads to DNA replication error (RER) phenotype. Microsatellite instability (MSI), reflecting a cellular deficiency in DNA mismatch repair (MMR), is now regarded as an important biomarker to predict the cellular genome mutation (Zhou et al., 2012). If uncorrected, these errors are fixed after a next round of replication as addition or deletion of one or more microsatellite sequences. This mutated phenotype manifests as MSI, and appears to play an important role in tumorogenesis and/or tumor progression. Marek's disease provides excellent model 
for the study of herpes virus-induced tumors both in experimental and natural conditions (Zhou et al., 2012).

Apart from a few candidate gene studies, most efforts to identify Marek 's disease resistance genes have used genome-wide QTL scans with microsatellite markers (Cheng et al., 2013). Two studies utilized ADO Llines 6 (MD resistant) and 7 (MD susceptible). Vallejo et al. (1998) and Yonash et al. (1999) identified 14 QTLs (7 significant and 7 suggestive) where the QTLs explained up to $75 \%$ of the genetic variance. By measuring not only disease incidence but also diseaserelated traits, the QTLs could be grouped by trait type. Some QTLs were associated almost exclusively with viremia levels and the remaining QTLs with disease, survival, tumor incidence, nerve enlargement, and other disease-associated traits, which suggests that disease resistance occurs at least at two levels: initial viral replication and cellular transformation (Cheng et al., 2013).

Genetic resistance to footrot in sheep varies between populations and phenotypes. The estimated heritability is between $0.10-0.20$ (Smith et al., 2012), indicating the potential capacity of microsatellite loci for effective selection for resistance.

Other agents causing unexplained types of scrapie or atypical scrapie first reported in Norway in 1998 are now widespread (Benestad et al., 2003; Orge et al., 2004; Moum etal., 2005). Recently, Lühken et al. (2007) have associated microsatellites MCMA53 and MCMA16 on sheep chromosome 15 with susceptibility to atypical scrapie. Other polymorphic microsatelittes also occur within the ovine and bovine PRNP gene (Geldermann et al., 2003; Luhken et al., 2007).

Candidate gene microsatellite variation in TCRG4 locus is associated with parasitism in wild bighorn sheep (Luikart et al.,2008). Catalase gene - SHP4 is associated with facial eczema disease resistance in sheep for ovine eczema (Phua et al., 1999).

Davies et al. (2006) studied BL4 for IgA QTL parasitic infection in Scottish blackface sheep. Two microsatellite markers (TGLA48 and BMC5221) are in the linkage group as genes with the gene ontology (GO; www.geneontology.org) code for defence response to Gram-negative bacterium (Smith et al., 2012). Studies on QTL affecting parasite resistance in cattle have been carried in USA (Gasbarre et al., 2002). For genetic analysis of the DNA polymorphism more than 200 microsatellite markers were tested and found at regular intervals (about $20 \mathrm{cM}$ ) across the entire genome. Preliminary results of QTL analysis show that an expected heterozygosity index was $50 \%$, and $45 \%$ for polymorphism information content (PIC). These data suggest that parasiteresistance is related to acquired immunity, associated with the interferon gamma gene $(I F N G)$ gene. The gene was also found as QTL for resistance to gastrointestinal nematodes in sheep.

In Germany the study on QTL for resistance to parasites was carried out on the Rhönschaf sheep (Janssen et al., 2002). Statistical analysis showed significant 
association between parameters of resistance (faecal egg count) and the markers OarCp73, DYMS1 and BM1815. The DYA gene (belonging to the class IIb subregion of the major histocompatibility complex - MHC) closely linked to the microsatellite DYMS1, is a possible candidate gene for resistance to Haemonchus contortus in sheep.

Indigenous (unimproved) breeds of sheep seemed to be significantly resistant or tolerant to parasites as compared with commercial (improved) breeds. The widest polymorphism among the MHC genes is found in locus DRBI which encodes the beta chain of the DR protein molecule, located on the surface of antigen-presenting cells. Charon et al. (2002) showed a significant association between microsatellite polymorphism in $D R B 1$ gene and the faecal nematode egg count on primitive Heatherheaded sheep. A total of 23 alleles were identified across the investigated gene fragment. Alleles $482 \mathrm{bp}$ and $530 \mathrm{bp}$ showed significant association with resistance to gastrointestinal nematodes, while the 568 bp allele was found related to susceptibility to parasites.

Bovine Progressive Degenerative Myeloencephalopathy (Weaver Syndrome) is a recessive neurological disease that has been observed in the Brown Swiss cattle breed since the 1970's in North America and Europe.

Weaver Syndrome was mapped to Bos taurus autosome (BTA) 4 by Georges et al. (1993), and the microsatellite (MS) marker TGLA116 (58.21 Mbp) was identified as a diagnostic marker due to its close linkage (estimated 3\% recombination rate) with the locus containing the Weaver allele. The authors have identified a microsatellite locus (TGLA116) closely linked to the weaver gene discovered in testing the hypotheses that the genetic disease in cattle - progressive degenerative myeloencephalopathy (weaver disease) is associated with increased milk production. TGLA116 and the weaver locus were assigned to bovine synteny group 13. The authors posted that this microsatellite marker could be used to identify weaver carriers, to select against this genetic defect, and to study the effect of the chromosomal region on milk production in Brown Swiss and other breeds of cattle.

The locus was later refined to a $10 \mathrm{Mbp}$ window between markers BMS2646 and MAF50 (46.31 and 56.42 Mbp, respectively) (Denise and Medrano, 2005). Weaver carrier animals were either identified from affected progeny or via a commercially available genetic test based upon the haplotype of 6 MS markers: RM188, MAF50, RM067, TGLA116, BM1224, and BM6458, within a $43.8 \mathrm{cM}$ region (McClure et al., 2013).

\section{Conclusion}

The development of molecular markers for genetic analysis has led to great increase in our knowledge of livestock genetics and our understanding of the structure and behaviour of animal genomes. 
In recent years, the demonstration of genetic polymorphism at the DNA sequence level has provided a large number of marker techniques with variety of applications. However, utilization of marker-based information for genetic improvement depends on the choice of an appropriate marker system for a given application.

Microsatellites have the highest heterozygosity among all marker types because of their high number of alleles. For as much as most RFLP, RAPD, AFLP and SNP markers are biallelic markers, they have a maximal heterozygosity value of 0.5. Thus, microsatellites are most informative as genetic markers. This feature makes microsatellites the unique marker system for identification of individuals such as parentage analysis, as well as the choice of markers for many other types of applications. The major application of microsatellite markers is for the construction of genetic linkage and QTL maps.

Although the MAS development still remains limited due to some limiting factors including biological factors (reproductive capacity) and many theoretical considerations related to the effectiveness of MAS, the ultimate use of STR markers is for mapping quantitative trait loci (QTL) and in marker assisted selection (MAS) in order to practice genomic selection in nucleus breeding programs. Developments in 'omics' technologies, such as genomic selection, may help overcome several of the limitations of conventional breeding programmes and will be especially beneficial in breeding for lowly heritable disease traits that only manifest themselves following exposure to pathogens or environmental stressors in adulthood.

Microsatellite sequences are most commonly employed in determining progress in genetic resistance to livestock diseases and control of genetic disorders in livestock animals. There continues to be very significant advances in efforts to control disease, with the potential for significant improvements to both performance and welfare. These advancements will included improved understanding of disease pathophysiology and epidemiology for improved disease control in farm animals.

\section{Molekularna genetika i SSR markeri kao nova praksa u genomskoj analizi farmskih životinja u reprodukciji i kontroli bolesti}

A.Teneva, K. Dimitrov, V. Caro Petrović, M.P.Petrović, I. Dimitrova, N.Tyufekchiev, N. Petrov 


\section{Rezime}

Molekularna genetika istražuje genetski sastav pojedinaca na nivou DNK. To uključuje identifikaciju i mapiranje molekularnih genetskih markera i genetskih polimorfizama. Molekularni genetski markeri (DNK markeri) su jedan od najmoćnijih sredstava genomske analize i pružaju mogućnost povezivanja naslednih osobina sa genomskim varijacijama. Tehnologija molekularnih markera se brzo razvila u poslednjoj deceniji, a dva oblika markera na bazi DNK, Simple Sequence Repeats (SSR), takođe poznati kao mikrosateliti, i polimorfizam pojedinačnih nukleotida - Single Nucleotide Polymorphisms (SNP) preovlađuju u primeni u modernoj genetskoj analizi.

Genomske sekvence - ponavljanja (Simple Sequence Repeats - SSR, mikrosateliti) se koriste za razne svrhe, uključujući označavanje gena, fizičko mapiranje, mapiranje genoma, procena genetičke raznovrsnosti, filogenetske i u svrhu genetičke konzervacije u uzgoju farmskih životinja. SSR analiza se uspešno primenjuju u verifikaciji roditeljstva, i analizi pedigrea, kao markeri bolesti i u pronalaženju mutacije i genetskih poremećaja kod farmskih životinja. Krajnja upotreba SSR markera je za mapiranje lokusa kvantitativnih osobina (QTL), selekciji pomoću markera (MAS), kako bi se u praksi primenjivala genomska selekciju i unapređenje zdravlja farmskih životinja. Razvoj u tehnologijama "omics“', kao što je genomska selekcija, može pomoći u prevazilaženju nekoliko ograničenja tradicionalnih odgajivačkih programa a posebno će biti korisna za oplemenjivanje i odgoj na nižu naslednost naslednih osobina bolesti koje se ispoljavaju tek nakon izloženosti patogenima ili ekološkim stresorima u odraslom dobu. Ovaj rad daje kratak pregled današnje primene mikrosatelit markera $u$ stočarstvu i daje značajan doprinos ukupnom zdravlju životinja uzgajanih na farmi i otpornosti na bolesti.

\section{References}

ABERLE K., DISTLO S. (2004): Domestication of the horse: results based on microsatellite and mitochondrial DNA markers. Arch. Tierz., Dummerstorf,47, 6, 517-535.

ACEVEDO-WHITEHOUSE K., VICENTE J., GORTAZAR C., HOFLE U., FERNANDEZ-DE-MERAI.G., AMOS W. (2005): Genetic resistance to bovine tuberculosis in the Iberian wild boar. Mol. Ecol., 14, 3209-3217.

ADAMOV N., MICKOV L., PETKOV V., ADAMOV M. (2011): Microsatellite markers for pedigree verification in cattle. Macedonian Journal of Animal Science, $1,1,9-15$.

ALTER L., FRANCINO O., SANCHEZ A. (2001): Microsatellite polymorphism in closely related dogs. J. Hered., 92, 276-279. 
ARCHIBALD A., ET AL. (1995): The PiGMaP consortium linkage map of the pig (Susscrofa). 6,157-75.

AWADALLA P, RITLAND K. (1997): Microsatellite variation and evolution in the Mimulusguttatus species complex with contrasting mating systems. Mol Biol Evol, 14, 1023-1034.

BARENDSE W, ARMITAGE S.M., KOSSAREK L.M., SHALOM A., KIRKPATRICK B.W., RYAN A. M., CLAYTON D., LI L., NEIBERGS H. L., ZHANG N.(1994): A genetic linkagemap of the bovine genome. Nat. Genet., 6, 227-235.

BEHL R., KAUL R., SHEORAN N., BEHL J., TANTIA M. S., VIJH R. K. (2002): Genetic identity of two Indian pig types using microsatellite markers. Anim. Genet., 33, 158-159.

BENESTAD S.L, THU B., BRATBERG B., SARRADIN P., SCHÖNHEIT J. ET AL. (2003): Cases of scrapie with unusual features in Norway and designation of a new type. Vet Rec, 153, 202-208.

BEUZEN, N. D., STEAR M. J., CHANG K. C. (2000): Molecular markers and their use in animal breeding. Vet. J., 160, 42-52.

BERRY D. P., BERMINGHAM L.M, GOOD M., MORE S.J. (2011): Genetics of animal health and disease in cattle. Irish Veterinary Journal, 64, 5,1-10.

BJORNSTAD G., ROED K. H. (2001): Breed demarcation and potential for breed allocation of horses assessed by microsatellite markers. Anim Genet, 32, 59-65.

BINADEL J., IAN M., IANNUCELLI N., AMIGUES Y., BOSCHER M. Y., BOURGEOIS F., CARITEZ J. C., GRUAND J., LEROY P., LAGANT H., QUINTANILLA R., RENARD C., GELLIN J., OLLIVIER L., CHEVALET C. (2001): Detection of quantitative trait loci for growth and fatness in pigs. Genet Sel Evol, 33, 289-309.

BLOUIN M.S. (2003): DNA-based methods for pedigree reconstruction and kinship analysis in natural populations. Trends in Ecology and Evolution, 18, 503511.

BOICHARD D, FRITZ S., ROSSIGNOL M.N., GUILLAUME F., COLLEAU J.J., DRUET T. (2006): Implementation of marker-assisted selection: practical lessons from dairy cattle. 8th World Congress on Genetics Applied to Livestock Production, August 13-18, Belo Horizonte, MG, Brasil.

BOTSTEIN D., WHITE R. L., SKOLNICK M., DAVIS R. W. (1980): Construction of a genetic map in man using restriction fragment length polymorphism. Am. J. Human Genet., 32, 314-331.

BOWCOCK A.M., RUIZ-LINARES A., TOMFOHRDE J., MINCH E., KIDD J.R., CAVALLI-SFORZA L. L. (1994): High resolution of human evolutionary trees with polymorphic microsatellites. Nature, 38, 455-457.

BOWLING A. T., EGGLESTON-STATT M.L, BYRNS G., CLARK R.S., DILEANIS S., WICTUM E. (1997): Validation of microsatellite markers for routine horse parentage testing. Anim Genet, 28, 247-252 
CABALLERO A., TORO M.A. (2002): Analysis of genetic diversity for the management of conserved subdivided populations. Conservation Genetics, 3, 289299.

CANON J., ALEXANDARIO I., BESSA C., CARLEOS Y., CARRETERO S., DONNER S., FERRAN N., GARCIA D., JORDANA J., LALOE D., PEREIRA A., SANCHEZ K., MOAZAMI-GOUDARZI K. (2001): Genetic diversity measures of local European beef cattle breeds for conservation purpose. Genet Selec Evol, 33, 311-332.

CHAKRABORTY R, MEAGHER T., SMOUSE P. (1988): Parentage analysis with genetic-markers in natural-populations. 1. The expected proportion of offspring with unambiguous paternity. Genetics, 118, 527-536.

CHARON K.M., MOSKWA B., RUTKOWSKI R., GRUSZCZYNSKA J., ŚWIDEREK W. (2002): Microsatellite polymorphism in DRB1 gene (MHC class II) and its relation to nematode faecaleggcount in Polish Heath Sheep. Journal of Animal and Feed Sciences, 11, 47-58.

CHENG H. H., KAISER P., LAMONT S. J. (2013): Integrated Genomic Approaches to Enhance

Genetic Resistance in Chickens. Annu Rev Anim Biosci, 1, 239-260.

COLTMAND W., WILSON K., PILKINGTON J.G., STEAR M.J., PEMBERTON J.M. (2001): A microsatellite polymorphism in the gamma interferon gene is associated with resistance to gastrointestinal nematodes in anaturally-parasitized population of Soay sheep. Parasitology 122, 571-582.

COPPIETERS W., VANDE A., PEELMAN L., DEPICKE R, VAN ZEVERAN A., BOUQUET Y.( 1993): Characterization of polymorphic microsatellite loci. Anim. Genet., 24, 163-179.

CRAWFORD A., ET AL. 1995. An autosomal genetic linkage map of sheep genome. Genetics, 140, 703-724.

DAVIES G., STEAR M.J., BENOTHMAN M., ABUAGOB O., KERR A., MITCHELL S., BISHOP S.C. (2006): Quantitative trait loci associated with parasitic infection in Scottish blackface sheep. Heredity, 96, 252-258.

DEKKERS J.C.M., HOSPITAL F. (2002): The use of molecular genetics in the improvement of agricultural populations. Nature reviews. 3, 22-32.

DEKKERS J. (2004): Commercial application of marker- and gene-assisted selection in livestock: Strategies and lessons, J Anim Sci, 82, 313-328.

DENISE S.K, MEDRANO J.F. (2005): Genetic analysis of the weaver (PDME) locus on bovine chromosome. USDA-CRIS update.

DORJI T., HANNOTE O., ARBENZ M., REGE J.,RODER W. (2003): Genetic diversity in indigenous cattle populations in Bhutan: implications for conservation. Asian-Aust. J. Anim. Sci. 16, 946- 951.

DURAN C., APPLEBY A. N., EDWARDS D., BATLEY J.(2009): Molecular Genetic Markers: Discovery, Applications, Data Storage and Visualisation.Current Bioinformatics, 4, 16-27. 
ELLEGREN H., CHAUDHARY B.P., JOHNSSON M., MARKLUND L., FREDHOLM M., GUSTAVSON I., ANDERSSON L. (1994): A primary linkage map of the porcine genome reveals a low rate of genetic recombination. Genetics. 137, 1089-1100.

ELLEGREN H. (2004): Microsatellites: simple sequences with complex evolution. Genetics, Nature reviews, 435-444.

ERHARDT G., WEIMANN C. (2007): Use of molecular markers for evaluation of genetic diversity and animal production. Arch. Latinoam. Prod. Anim., 15 (Supl. 1), 63-66.

FAO. (2011): Molecular genetic characterization of animal genetic resources. FAOAnimal Production and Health Guidelines. No. 9, Rome.

FREDHOLM M., WINTERO A. K., CHRISTENSEN K., KRISTENSEN B., NIEHRON P. B., DAVIES W., ARCHIBALD A. (1993): Characterization of 24 porcine $(\mathrm{dA}-\mathrm{dC}) \mathrm{n}$.(dT-dG)n microsatellites: genotyping of unrelated animals from four breeds and linkage studies. Mam. Genome, 4, 187-192.

FREDHOLM, M., WINTERO A.K. (1996): Efficient resolution of parentage in dogs by amplification of microsatellites. Anim Genet, 27, 19-23.

FUJII J., OTSU K., DE ZORZATO F., LEON S., KHANNA V., WEILER J., O'BRIEN P. J., MACLENNAN, D. (1991): Identification of a mutation in porcine ryanodine receptor associated with malignant hyperthermia. Science, 253, 448451.

GASBARRE L.C., SONSTEGARDS T., VAN TASSELL C., PADILHA T. ( 2002): Detection of QTL affecting parasite resistance in a selected herd of Angus cattle. Proceedings of the 7th World Congress on Genetics Applied to Livestock Production, Montpellier, France, session 13, communication 13-07.

GELDERMANN H., PRUESS S., ECKERT J., HAN Y., OLLESCH K. (2003): Analysis of polymorphic microsatellites within the bovine and ovine PRNP protein (PRNP) genes. Anim Genet, 34, 283-289.

GENTILINI F., TURBA M.E., ANDREANI G. (2004): DNA Fingerprinting Using Microsatellites to Solve a Parentage Testing in the Boxer Breed. Veterinary Research Communications, 28, 185-188.

GEORGES M., DIETZ A., MISHRA A., NIELSEN D., SARGEANT L., SORENSON A., STEELE M, ZHAO X., LEIPOLD H., WOMACK J., LATHROP M. (1993): Microsatellite mapping of the gene causing weaver disease in cattle will allow the study of an associated quantitative trait locus. Proc Natl Acad Sci USA, 90, 1058-1062.

GEORGES M, NIELSEN D., MACKINNON M., MISHRA A., OKIMOTO R., PASQUINO A. T., SARGEANT L. S., SORENSEN A., STEELE M. R., ZHAO X., WOMACK J. E., HOESCHELE I. (1995): Mapping Quantitative Trait Loci Controlling Milk Production in Dairy Cattle by Exploiting Progeny Testing. Genetics. 139, 907-920. 
GRISART B., COPPIETERS W., FARNIR F., KARIM L., FORD C., BERZI P., CAMBISANO N., MNI M., REID S., SIMO P., SPELMAN R., GEORGES M., SNELL R. (2002): Positional candidate cloning of a QTL in dairy cattle: Identification of a missense mutation in the bovine DGAT1 gene with major effect on milk yield and composition. Genome Research 12, 222-231.

GROENEVELD L.F., LENSTRA, J.A., HE GLOBALDIV CONSORTIUM. (2010): Genetic diversity in livestock breeds. Animal Genetics, 41(suppl. 1), 6-31. GUERAND M., MAHLA R., LAGNEAUX D., AMIGUES Y., PALMER E., BEZARD J. (1997): Parentage testing of day 10 equine embryos by amplified PCR analysis of microsatellites. Equine Vet J, Suppl. 25, 69-71.

GUPTA M, CHYI YS, ROMEROSEVERSON J, OWEN JL. (1994): Amplification of DNA markers from evolutionarily diverse genomes using single primers of simple-sequence repeats. Theor Appl Genet, 89, 998-1006.

HANOTTE O., RONIN Y., AGABA M., NILSSON P., GELHAUS A., HORSTMANN R., SUGIMOTO Y., KEMP S., GIBSON J., KORO A., SOLLER M., TEALE A. (2003): Mapping of quantitative trait loci controllingtrypanotolerance in a cross of tolerant West African N'Dama and susceptible East African Boran cattle. Proc Natl Acad Sci USA, 100, 7443-7448. HASAN L., VOGELI P., NEUENSCHWANDER S., STOLL P., MEIJERINK E., STRICKER C., JORG H., STRANZINGER G. (1999): The L-gulonogammalactone oxidase gene (GULO) which is a candidate for vitamin C deficiency in pigs maps to chromosome 14. Anim Genet, 30, 309-312.

HARDER B., BENNEWITZ J., REINSCH N., THALLER G., THOMSEN H., KÜHN C., SCHWERIN M., ERHARDT G., FÖRSTER M., REINHARDT F., KALM E. (2006): Mapping of quantitative trait loci for lactation persistency traits in German Holstein dairy cattle. J Anim Breed Genet, 123, 89-96.

HAYES B.J., BOWMAN P. J., CHAMBERLAIN A. J., GODDARD M. E. (2009): Genomic selection in dairy cattle: Progress and challenges. J Dairy Sci, 92, 433443.

HIENDLEDER S., THOMSEN H., REINSCH N., BENNEWITZ J., LEYHEHORN B., LOOFT C., XU N., MEDJUGORAC I., RUSS I., KÜHN C., BROCKMANN G.A., BLÜMEL J., BRENIG B., REINHARDT F., REENTS R., AVERDUNK G., SCHWERIN M., FÖRSTER M., KALM E., ERHARDT G. (2003): Mapping of QTL for body conformation and behaviour in cattle. J of Heredity, 94, 496-506.

HINES H.C. ( 1999): Blood groups and biochemical polymorphisms. In: Genetics of cattle. Eds. Fries, R. and Ruvinsky, A., CABI Publishing.

HIROOKA H., DEKONING D. J., HARLIZIUS B., VAN ARENDONK J. A., RATTINK A.P., GROEHEN M. A., BRASCAMP E.W., BOVENHIUS H. (2001): A whole genome scan for quantitative trait loci affecting teat number in pigs. $J$ Anim Sci, 79, 2320-2326. 
JANSSEN M., WEIMANN C.,GAULY M., ERHARDT G. (2002): Association between infections with Haemonchuscontortusand genetic markers on ovine chromosome 20. Proceedings of the 7th World Congress on Genetics Applied to Livestock Production, Montpellier, France, session 13, communication 13-11.

JORDANA J., ALEXANDRINO P., BEIJA-PERIERA A., BESSA I., CANON J., CARRETERO Y., ET AL. (2003): Genetic structure of eighteen local south European beef cattle breeds by $F$-statistics. J Anim Genet, 120, 73-87.

IHARA N., TAKASUGA A., MIZOSHITA K., TAKEDA H., SUGIMOTO M., MIZOGUCHI Y., HIRANO T., ITOH T.H.T., WATANABE T., REED K.M., SNELLING W.M., KAPPES K.M., BEATTIE C.W., BENNETT G.L., SUGIMOTO Y. (2004): A comprehensive genetic map of the cattle genome based on 3802 microsatellites. Genet. Res., 14 (10A), 1987-1998.

KASHI Y., KING D., SOLLER M. (1997): Simple sequence repeats as a source of quantitative genetic variation. Trends Genet, 13, 74-78.

KAPPES, S. M., KEELE J. W., STONE R. T., MCGRAW R. A., SONSTEGARD T. S., SMITH T. P, LOPEZ-CORRALES W. L., BEATTIE C. W. (1997): A second generation linkage map of the bovine genome. Genome Res., 7, 235-249.

KATTI M.V., RANJEKAR P.K., GUPTA V.S. (2001): Differential distribution of simple sequence repeats in eukaryotic genome sequences. Mol Biol Evol, 18, 11611167.

KAUL R., SHEORAN N., TANTIA M. S., VIJH R. K., BEHL R.(2001): Evaluation of genetic variability of 13 microsatellite markers in native Indian pigs. J. Genet, 80, 149-153.

KAUPE B., BRAND, H., PRINZENBERG E. M., ERHARDT G. (2007): Joint analysis of the influence of CYP11B1 and DGAT1 genetic variation on milk production, somatic cell score, conformation, reproduction, and productive lifespan in German Holstein cattle. J Anim Sci, 85, 11-21.

KHATKAR M.S, THOMSON P.C, TAMMEN I., RAADSMA H.W. (2004): Quantitative trait loci mapping in dairy cattle: review and meta-analysis. Genetics Selection Evolution, 36, 163-90.

KIM K. S., YEO J., CHOI C. (2002): Genetic diversity of northeast Asian cattle based on microsatellite data. Anim. Genet. 33, 201-204.

KRIEGESMANN B., JANSEN S., BAUMGARTNER B. G., BRENIG B. (1997): Partial genomic structure of the bovine CD18 gene and the refinement of test for bovine leukocyte adhesion deficiency. J. Dairy Sci., 80, 2547-2549.

KÜHN C., BENNEWITZJ., REINSCH N., XU N., THOMSEN H., LOOFT C., BROCKMANN C. A, SCHWERIN M., WEIMANN C., HIENDLEDER S., ERHARDT G., MEDJUGORAC I., FÖRSTER M., BRENIG B., REINHARDT F., REENTS R., RUSS I., AVERDUNK G, BLÜMEL J., KALM, E. (2003): Quantitative trait loci mapping of functional traits in the German Holstein cattle population. J. Dairy Sci., 86, 360-368. 
LAVAL G., IANNUCCELLI N., LEGAULT C., MILAN D., GROENEN M. A., GIUFFRA E., ANDERSSON L., NISSEN P. H.,. JORGENSEN C. B, BEECKMANN P., GELDERMANN H. FOULLEY J. L., CHEVALET C., OLLIVIER L. (2000): Genetic diversity of eleven European pig breeds. Genet Sel Evol, 32, 187-203.

LI, X, LI K., FAN B., GONG Y., ZHAO S., PENG Z., LIU B. (2000b): The genetic diversity of seven pig breeds of China, estimated by means of microsatellites. Asian-Aus. J. Anim. Sci., 13, 1193-1195.

LI Y.C., KOROL A.B., FAHIMA T., BEILES A., NEVO E. (2002): Microsatellites: genomicdistribution, putative functions and mutational mechanisms: a review. Mol Ecol, 11, 2453-2465.

LUHKEN G., ZIELENIEWIC Z. D., BRANDT H.R., BUSCHMANN A., GROSCHUP M.H., ERHARDTG. (2007): Microsatellites MCMA53 and MCMA16 on OAR15 are associated with susceptibility to atypical scrapie. Anim Genet, 38, 88-89.

LUIKART G., ENGLAND P. (1999): Statistical analysis of microsatellite DNA data. Trends in Ecology and Evolution, 14, 253-256.

LUIKART G., ENGLAND P., TALLMON D., JORDAN S., TABERLET P. (2003): The power and promise of population genomics: From genotyping to genome typing. Nat. Rev. Genet.,4, 981-994.

LUIKART G., PILGRIM K., VIST, J., EZENWA V.O., SCHWARTZ M.K. (2008): Candidate gene microsatellite variation is associated with parasitism in wild bighorn sheep. Biol Lett, 4, 228-231.

MACHUGH D., SHRIVER M., LOFTUS R., CUNNINGHAM P., BRADLEY D. (1997): Microsatellite DNA variation and the evolution, domestication and phylogeography of taurine and zebu cattle (Bostaurusand Bosindicus). Genetics, 146, 1071-1086.

MALEK M., DEKKERS J. C., LEE H. K., BAAS T. J., ROTHSCHILD M. F. (2001a): A molecular genome scan analysis to identify chromosomal regions influencing economic traits in the pigs. 1. Growth and body composition. Mamm Genome, 12, 630-636.

MALEK M., DEKKERS J. C.., LEE H. K., BAAS T. J., PRURA K., HUFFLONERGAN E., ROTHSCHILD M. F. (2001b): A molecular genome scan analysis to identify chromosomal regions influencing economic traits in pig Meat and muscle composition. Mamm Genome, 12, 637-645.

MARKLUND L., WYSTROM P. E., STERN S., ANDERSSON-EKLUND L., ANDERSSON L. ( 1999): Confined quantitative trait loci for fatness and growth on pig chromsome 4. Heredity, 82, 134-141.

MARLE-KÖSTER E., NEL L.H. (2003): Genetic markers and their application in livestock breeding in South Africa: A review. South African Journal of Animal Science, 33, 1-10. 
MARTÍNEZ A.M., DELGADO J.V., RODERO A., VEGA-PLA J.L. (2000): Genetic structure of the Iberian pig breed using microsatellites. Animal Genetics, 31: 295-301.

MAUDET C., LUIKART G., TABERLET P. (2002): Genetic diversity and assignment test among seven French cattle breeds based on microsatellite DNA analysis. J Anim Sci, 80, 942-950.

MCCLURE M., KIM E., BICKHART D., NULL D., COOPER T., COLE J., WIGGANS G., AJMONE-MARSAN P., COLLI L., SANTUS E., LIU G., SCHROEDER S., MATUKUMALLI L., VAN TASSELL C., SONSTEGARD T. (2013): Fine Mapping for Weaver Syndrome in Brown Swiss Cattle and the Identification of 41 Concordant Mutations across NRCAM, PNPLA8 and CTTNBP2. PLOS ONE, 8,3,1-16.

MCNIEL E.A., GRIFFIN K. L., MELLETT A. M., MADRILL N. J., MICKELSON J. R. (2007): Microsatellite Instability in Canine Mammary Gland Tumors. J. Vet. Intern. Med., 21 (5), 1034-40.

MEIJERINK E., NEUENSCHWANDER S., FRIES R., DINTER A., BERTSCHINGER H.U., STRANZINGER G., VÖGELI, P. (2000): A DNA polymorphism influencing alpha $(1,2)$ fucosyltransferase activity of the pig FUT1 enzyme determines susceptibility of small intestinal epithelium to Escherichia coli F18 adhesion. Immunogenetics, 52,129-136.

METTA M., KANGINAKUDRU S., GUDISEVA N., NAGARAJU J. (2004): Genetic characterization of the Indian cattle breeds, Ongole and Deoni (Bos indicus), using microsatellite markers - a preliminary study. BMC Genetics, 5, 16. MEUWISSEN T. H. E., GODDARD M. E. (1996): The use of marker haplotypes in animal breeding schemes. Genetic Selection and Evolution, 28, 161-176.

MOXON E.R., WILLS C. (1999): DNA MICROSATELLITES: AGENTS OF EVOLUTION? SCI.AM, 280: 94-99.

MOUM T, OLSAKER I, HOPP P, MOLDAL T, VALHEIM M ET AL. (2005): Polymorphisms at codons 141 and 154 in the ovine prion protein gene are associated with scrapie Nor98 cases. J Gen Virol, 86, 231-235.

MUIR, W.M. (2003): Incorporating molecular information in breeding programmes: applications and limitations. In W.M. Muir \& S.E. Aggrey, eds. Poultry Genetics, Breeding and Biotechnology, pp. 549-562. Wallingford, UK, CABI Publishing.

MUKESH M., SODHI M., BHATIA S., MISHRA B. (2004): Genetic diversity of Indian native cattle breeds as analysed with 20 microsatellites. J Anim. Breed Genet, 121, 416-424.

NAQVI A.N. (2007): Application of Molecular Genetic Technologies in Livestock Production: Potentials for Developing Countries. Advances in Biological Research, 1 (3-4), 72-84.

NIDUP K, AYALEW W., DANBARO G., GONGORA J., MORAN C. (2010a).Genetic structure and diversity of indigenous pigs of Papua New 
Guinea.Annual Postgraduate Conference.P53, 1-2 November. Camperdown Campus, Faculty of Veterinary Science, University of Sydney, Australia.

NIDUP K, G., SILVA D., JOSHI R., PEM J., GONGORA J., MORAN C. (2010b). Genetic Diversity of Pigs (Sus scrofa) in the Himalayas and Sri Lanka. $32^{\text {nd }}$ International Society for Animal Genetics Conference, Edinburgh.

NIU R., SHANG H. T., WEI H., HUANG Z. B., ZENG Y. Z. (2001): Genetic analysis of 35 microsatellite loci in 5 linkages of Xishuangbanna miniature pig inbred lines. Yi ChuanXueBao, 28, 518-526.

OLLIVIER L, ALDERSON L., GANDINI G., FOULLEY J., HALEY C., ET AL. (2005): An assessment of European pig diversity using molecular markers: Partitioning of diversity among breeds. Conservation Genetics 6, 729-741.

OLLIVIER, L. (2009): European pig genetic diversity: a minireview. Animal 3, 915-924

ORGE L., GALO A., MACHADO C., LIMA C., OCHOA C., ET AL. (2004): Identification of putative atypical scrapie in sheep in Portugal. J Gen Virol, 85, 3487-3491.

PANDEY A., REKHA S., YATENDER S., PRAKACHAND B., AHLAWAT S. (2006): Genetic diversity studies of Kherigarh cattle based on microsatellite markers. Journal of Genetics, V. 85, 2,117-122

PASZEK A. A., FLICKINGER G. H., FONTANESI L., ROHRER G.A., ALEXANDER L., BEATTIE C. W., SCHOOK L. B. (1998b): Livestock variation of linked microsatellite markers in diverse Swine breeds. Anim. Biotech. 9, 55-66. PHUA S.H., DODDS K., MORRIS C., PATERSON K., MCEWAN J., GARMONSWAY H., TOWERS N., CRAWFORD A. (1999): Catalase gene is associated with facial eczema disease resistance in sheep. Anim. Genet. 30, 286295.

PEELMAN L. J., MORTIAUX F., VAN ZEVERAN A., DANRERCOER A., MOMMENS G., COOPMAN F., BOUQUET Y., BORNY A., RENAVILLE R., PORTETELLE D. (1998): Evaluation of the genetic variability of 23 bovine microsatellite markers in four Belgian cattle breeds. Anim. Genet. 29, 161-167.

PRINZENBERG E. M., WEIMANN, C., BRANDT H., BENNEWITZ J., KALM E., SCHWERIN M., ERHARDT G. (2003): Polymorphism of the bovine CSN1S1 promoter: linkage mapping, intragenic haplotypes, and effects on milk production traits. J. Dairy Sci., 86, 2696-2705.

SCHLOTTERER C., TAUTZ D. (1992): Slippage synthesis of simple sequence DNA.Nucleic Acids Research, 20, 211-215.

SCHLOTTERER C. (2000): Evolutionary dynamics of microsatellite DNA.Chromosoma, 109, 365-371.

SCHULMAN N.F., VIITALA S.M., DE KONING D.J., VIRTA D.J., MAKITANILA J., VILKKI J.H.

(2004): Quantitative trait loci for health traits in Finnish Ayrshire cattle. J. Dairy Sci., 87, 443-449. 
SELKOE K.A., TOONEN R.J. (2006): Microsatellites for ecologists: a practical guide to using and evaluating microsatellite markers. Ecol. Letters, 9, 615-629.

SMITH E.M, HOFFMAN J., GREEN L., AMOS W. (2012): Preliminary association of microsatellite heterozygosity with footrot in domestic sheep. Livestock Science, 143, 293-299.

SOTIRAKOPOULOS A. J., ARMSTRONG P. J., HEATH L., MADRILL N. J., MCNIEL E. A. (2010): Evaluation of microsatellite instability in urine for the diagnosis of transitional cell carcinoma of the lower urinary tract in dogs. J. Vet. Intern Med., 24(6), 1445-51.

SUBRAMANIAN S., MISHRA R.K, SINGH L. (2003): Genome-wide analysis of microsatellite repeats in humans: their abundance and density in specific genomic regions. Genome Biol., 4, R13.

TABERLET P., VALENTINI A., REZAL H., NADERI S., POMPANON F., NEGRINI R., AJMONE-MARSAN P.( 2008): Are cattle, sheep and goats endangered species? Mol.Ecology, 275-284.

TENEVA A., TODOROVSKA E., TYUFEKCHIEV N., KOZELOV L., ATANASSOV A., FOTEVA S., RALCHEVA S., ZLATAREV S. (2005): Molecular characterization of Bulgarian livestock genetic resources. I. Genetic diversity in Bulgarian Grey cattle as revealed by microsatellite markers. Biotechnology in Animal Husbandry, 21, 5-6, 35-41.

TENEVA A ., E. TODOROVSKA, N. TYUFEKCHIEV, A. STELLA , P. BOETTCHER, I. DIMITROVA(2007):Molecular characterization of Bulgarian livestock genetic resources. II. Microsate llite variation within and among Bulgarian cattle breeds. Biotechnology in Animal Husbandry, 23, 5-6, 227-242.

TENEVA A., DIMITROVA I., GEORGIEV G., POLIHRONOVA L., IVANOVA K. (2009): Molecular characterization of Bulgarian livestock genetic resources and their optimized utilization for animal production. FAO/IAEA International Symposium on Sustainable Improvement of animal Production and Health, 8-11 June 2009, Vienna, Austria, Synopses -126-127

TENEVA A. (2009): Molecular markers in animal genome analysis. 9-th International Symposium Modern Trends in Livestock Production, Belgrade, Biotechnology in Animal Husbandry, 25, 5-6, 1267-1285.

A.TENEVA, PETROVIĆ P.M (2010): APPLICATION OF MOLECULAR MARKERS IN LIVESTOCK IMPROVEMENT. Biotechnology in Animal Husbandry $26: 135-154$.

THUY, N., MELCHINGER W., KUSS A., CUONG N., BARTENSCHLAGER H., GELDERMANN H. (2006): Comparison of Vietnamese and European pig breeds using microsatellites. Journal of Animal Science 84, 2601-2608.

TAKAHASHI H., TSUDZUKI M., SASAKI O., NIIKURA J., INOUEMURAYAMA M., MINEZAWA M., (2005): A chicken linkage map based on microsatellite markers genotyped on a Japanese Large Game and White Leghorn cross. Anim. Genet., 36(6), 463-7. 
TAKEZAKI, N., NEI, M. (1996): Genetic distances and reconstruction of phylogenetic trees from microsatellite DNA.Genetics, 144, 389-399.

TAUTZ, D., RENZ M..(1984): Simple sequences are ubiquitous repetitive components of eukaryotic :genomes. Nucleic Acids Res., 12, 4127-4138.

TAUTZ, D. (1989): Hypervariability of simple sequences as a general source for polymorphic DNA markers. Nucleic Acids Research, 17(16), 6463-6471.

TORO, M.A., FERNÁNDEZ J., CABALLERO A. (2009): Molecular characterization of breeds and its use in conservation. Livestock Science, 120, 174195.

TÓTH G., GÁSPÁRI Z., JURKA J. (2000): Microsatellites in different eukaryotic genomes: survey and analysis. Genome Res.10, 967-981.

VALLEJO R.L, BACON L.D, LIU H.C, WITTER R.L, GROENEN M.A, ET AL. (1998): Genetic mapping of quantitative trait loci affecting susceptibility to Marek's disease virus induced tumors in F2 intercross chickens. Genetics, 148, 349-60.

WALSH B., (2000): Minireview: Quantitative genetics in the age of genomics. Theor. Pop. Biol., 59, 175-184.

WEIR A. ANDERSON, HEPLER A.(2006): Genetic relatedness analysis: modern data and new challenges. Nature reviews, Genetics, 7, 771-781.

WILLIAMS J. (2005): The use of marker-assisted selection in animal breeding and biotechnology.Rev. sci. tech. Off. int. Epiz., 24 (1), 379-391.

WINTER A., KRÄMER W., WERNER F. A. O., KOLLERS S., KATA S., DURSTEWITZ G., BUITKAMP J., WOMACK J. E., THALLER G., FRIES. R. (2002): Association of a lysine - 232/alanine polymorphism in a bovine gene encoding acyl-CoA diacylglycerolacyltransferase (DGAT1) with variation at a quantitative trait locus for milk fat content. Proc. Nat. Academy Sci. USA, 99, $9300-9305$.

YONASH N., BACON L.D, WITTER R.L, CHENG H.H. (1999): High resolution mapping and identification of new quantitative trait loci (QTL) affecting susceptibility to Marek's disease. Anim. Genet., 30, 126-35.

ZHOU Z., YAO D., QIU Y., YANG D. (2012): Microsatellite instability in Marek's Disease Virusinfected primary chicken embryo fibroblasts.Virology Journal, 9, 193.

Received 13 June 2013; accepted for publication 26 July 2013 